\title{
Baseline trace metals in water and sediment of the Baleh River-a tropical river in Sarawak, Malaysia
}

\author{
Siong Fong Sim • Hui Ping Chai • Lee Nyanti • \\ Teck Yee Ling • Jongkar Grinang
}

Received: 18 April 2016/Accepted: 24 August 2016/Published online: 30 August 2016

(C) Springer International Publishing Switzerland 2016

\begin{abstract}
Quantitative indices are classically employed to evaluate the contamination status of metals with reference to the baseline concentrations. The baselines vary considerably across different geographical zones. It is imperative to determine the local geochemical baseline to evaluate the contamination status. No study has been done to establish the background concentrations in tropical rivers of this region. This paper reports the background concentrations of metals in water and sediment of the Baleh River, Sarawak, derived based on the statistical methods where the areas possibly disturbed are distinguished from the undisturbed area. The baseline levels of six elements in water determined were $\mathrm{Al}$ $(0.34 \mathrm{mg} / \mathrm{L}), \mathrm{Fe}(0.51 \mathrm{mg} / \mathrm{L}), \mathrm{Mn}(0.12 \mathrm{mg} / \mathrm{L}), \mathrm{Cu}$ $(0.01 \mathrm{mg} / \mathrm{L}), \mathrm{Pb}(0.03 \mathrm{mg} / \mathrm{L})$, and $\mathrm{Zn}(0.05 \mathrm{mg} / \mathrm{L})$. Arsenic and selenium were below the detection limit. For sediment, the background values were established according to statistical methods including (mean $+2 \sigma$ ), iterative $2 \sigma$, cumulative distribution frequency, interquartile, and calculation distribution function. The background values derived using the iterative $2 \sigma$ algorithm and calculated distribution function were relatively lower. The baseline levels calculated were within the range reported in the literatures mainly from tropical and subtropical regions. The upper limits proposed for nine elements in sediment were $\mathrm{Al}(100,879 \mathrm{mg} / \mathrm{kg}), \mathrm{Cr}$
\end{abstract}

S. F. Sim $(\bowtie) \cdot$ H. P. Chai · L. Nyanti · T. Y. Ling •

J. Grinang

Faculty of Resource Science and Technology, Universiti Malaysia

Sarawak, 94300 Kota Samarahan, Sarawak, Malaysia

e-mail: sfsim@unimas.my
(75.45 mg/kg), Cu (34.59 mg/kg), Fe $(37,823 \mathrm{mg} / \mathrm{kg})$, $\mathrm{Mn}(793 \mathrm{mg} / \mathrm{kg}), \mathrm{Ni}(22.88 \mathrm{mg} / \mathrm{kg}), \mathrm{Pb}(27.26 \mathrm{mg} / \mathrm{kg})$, $\mathrm{Zn}(70.64 \mathrm{mg} / \mathrm{kg})$, and $\mathrm{Hg}(0.33 \mathrm{mg} / \mathrm{kg})$. Quantitative indices calculated suggest low risk of contamination at the Baleh River.

Keywords Urbanization · Trace metals · Geochemical baseline - Quantitative indices

\section{Introduction}

Rivers are very vulnerable to environmental changes where continuous development often leads to various undesirable consequences. The natural process with accelerated urbanization has substantially increased the metal loading of rivers; hence, continuous monitoring and appraisal of river water quality is imperative. For trace metals, the assessment often involves determination of metal contents, evaluation of the contamination status, and identification of hotspots. This is classically examined based on various quantitative indices such as geoaccumulation index, contamination factor, and enrichment factor that are derived with reference to the background concentrations resulting from weathering and dissolution of naturally occurring metals. It is often called the geochemical baseline where numerous studies employ the world surface rock and the world river water average as the reference (Martin and Meybeck 1979; Vowotor et al. 2014; Haydar et al. 2014; Hasan et al. 2015).

Oste et al. (2011) points out that there are considerable variations in the background levels from different 